\title{
Decongesting Prisons in Nigeria: the EBSU Law Clinic model
}

\author{
Dr Amari Omaka $\mathrm{C}^{1}$
}

Associate Professor of Law

\begin{abstract}
Due to the growing problems of overcrowding and prison congestion in Nigeria, the need to conduct this pro bono study became imperative. This study is a needs assessment, evaluation and fact finding of the challenges and access to judges problems of detainees of Abakaliki and Afikpo Federal Prisons in Ebonyi State Nigeria. Bearing in mind the UN Standard Minimum Rules and other instruments in international law, the project report generally captures the following information:-
\end{abstract}

- State of the Structure of the prisons

- Infrastructure at the prisons

- Facilities at the prisons

- Welfare of the inmates at the prison

- Welfare of the prisons staff

- Access to Justice by the inmates and

1 This paper was presented by Prof Dr Amari Omaka C at the $8^{\text {th }}$ IJCLE Conference at Northumbria University Newcastle Upon Tyne, England United Kingdom July 7, 2010. he carried out this project in liaison with clinicians of Ebonyi State University Law Clinic Abakaliki. Financial Support for the exercise was provided by Open Society Justice Initiative (OSJI). Special thanks to the Network of University Legal Aid Institutions (NULAI) and Open Society Justice Initiative (OSJI) for facilitating and sponsoring this prison project respectively. We appreciate the Vice Chancellor of Ebonyi State University Abakaliki, Prof. Francis Idike and Ebonyi State University management for giving us the enabling environment to conduct this study. We specially thank the Deputy Controller of Prisons in Charge of Abakaliki prisons DCP Oluwasemire S.I for facilitating our visit to the prisons. We also thank the Deputy Controller Afikpo prisons for allowing then students access to the prisons for this work, despite several challenges and bottlenecks. We also remain grateful to the Chief Judge of Ebonyi State, Justice Aloy Nwankwo, the Attorney General of Ebonyi State, Barr. Jossy Eze among numerous others that participated in imbibing ethical values to our students before entry to the prisons for the pro bono work. 
- Other ancillary issues such as children in prison, over age in prison, nature of offences etc.

In carrying out this study, empirical method of data collection and analysis was used. The two prisons in the state were visited and 250 prisoners responded to both the questionnaire and direct interview. Some staff of the Nigerian Prison Service and warders were also interviewed. The findings of this study were significant and highly revealing. The study specifically highlights certain issues of concern and proffers recommendations to address identified challenges. The report would serve as a national and international reference material as well as a programmatic tool for working out specific programmes and interventions to address the myriad problems facing the Nigerian prison system specifically, and the criminal justice administration system in Nigeria generally. The findings in this project are significant, the recommendations rich, we enjoin the government and development partners to implement them.

\section{Outline:}

The paper comprises five parts, with the following outline:

\section{Part I}

1.1 Background of the Study

1.2 Statement of the Problem

1.3 Project Objectives

1.4 Delimitation of the Area of the Project

1.5 Significance of the Project / Expected Outcome

1.6 Limitations / Challenges of the Prison Project

\section{Part 2}

\section{RESEARCH METHODOLOGY}

\subsection{Selecting Sample Population}

\subsection{Research Design}

2.3 Sample Design

2.4 Instruments of Data Collection

2.5 Modus operandi

\section{Part 3}

PRESENTATION, ANALYSIS OF DATA AND FINDINGS

\subsection{Introduction}

3.2 Data Presentation from Abakaliki Prison Respondents

3.3 Data presentation from Afikpo Prisons Respondents 


\section{Part 4}

SUMMARY OF FINDINGS

\section{Part 5}

\section{RECOMMENDATIONS AND CONCLUSION}

5.1 Recommendations

5.2 Conclusion

\section{Appendix A: Questionnaire}

\section{Part I}

\section{0 Introduction}

The Abakaliki and Afikpo prison project is a programme designed to ascertain the number of inmates at the prison. Those that are awaiting trial, those that are serving their sentence and those that are just remanded there by the magistrate or such like courts that have no jurisdiction on that particular matter. In addition, this project aims at knowing the welfare of the inmates in Abakaliki prisons. This welfare includes their feeding, health condition, educational support. To know whom amongst them needs a lawyer. This study became imperative because, from the available literature, the prison service in Nigeria has for many years been faced with many challenges. This is as a result of many factors, including overcrowding, inefficient criminal justice system, inadequate accommodation for both inmates and prison officers, high number of awaiting trial cases, obsolete/dilapidated infrastructural facilities. Others include; lack of recreational and vocational facilities, poor feeding for inmates, etc. The study was conducted with a view to collating data on these and bringing such to the attention of Government and development partners in order to reverse the trend.

\subsection{Background of the Study}

From available statistics, ${ }^{2}$ there are 227 prisons in Nigeria, spread across the six geo-political zones of the country. Available literature ${ }^{3}$ shows that these prisons, most of which were built by the colonial government, harbour more untried inmates than those properly convicted, some of which include children and women. The facilities are dilapidated and most of the inmates have no access to justice, and the facilities are in a state of decay. ${ }^{4}$ The prisons' congestion is a serious affront

2 However 133 prisons was reported as visited during the National Prison Audit Report 2007-2008, conducted by the National Human Rights Commission in partnership with UNDP, NORAD et al

3 Nigeria National Prison Audit Report 2007-2008

4 Ibid 
to human rights. In pre-trial cases, nationwide, most detainees have no legal representation ${ }^{5}$, case processing is slow, remand periods are exceeded, charge sheets frequently get lost and many cases lack the necessary evidence to prosecute them, making a mockery of a five-year wait for a trial that can only end in acquittal ${ }^{6}$. In Nigeria, prisons are grossly congested. Records ${ }^{7}$ have it that they are overcrowded to a capacity of as much as $250 \%$. Kirikiri Maximum Prison for instance, built for 956 prisoners is occupied by over 2,600 inmates, the majority of whom are awaiting trial. ${ }^{8}$ Prison overcrowding is a major concern of the Nigerian criminal justice system. Remand prisoners account for a substantial contribution to the problem of congestion in Nigerian prisons. ${ }^{9}$ A greater part of awaiting trial detainees in the prisons are held under the holding charge ${ }^{10}$ and many have spent up to ten years awaiting trial ${ }^{11}$.

For a long time, Nigerian prisons have been centres of human rights abuses. ${ }^{12}$ People are detained unlawfully for as long as the police want. ${ }^{13}$ Nevertheless, in spite of the sad fact that prison congestion has become a "national embarrassment", not much has been known about the issue of prison decongestion in law textbooks in the country. A careful research and perusal of our books have unearthed the sad reality that our libraries do not contain much information about prison decongestion. ${ }^{14}$ Prison congestion can be said to result if the number of prison inmates in a prison yard exceeds the number it is originally meant to accommodate, leading to inconveniences on the inmates as well as difficulty of control on the authorities concerned. Prison decongestion thus means the reduction in the amount of inmates. ${ }^{15}$ Reduction of the inmate intakes in prison to the available space becomes necessary if one looks at the inconveniences obtainable, to the inmates, the authority and the public. Little wonder, disease spread, violent break up of prisons and general public fear occurs, negating the essence of prison for reformation. ${ }^{16}$

In a public discourse organised recently by the "Detainees and Indigent Help Centre", resource fellows identified undue delay in criminal trial as one of the causes of prison congestion. This is more so because the cases of awaiting trial detainees are not disposed of in a good time. The forum further observed that where advice is sought from the Director of Public Prosecution, it may take months or even years to obtain because of the bureaucratic bottleneck in the administration of

5 The Prison Decongestion Project in Nigeria: An Appraisal by Mbanefo Ifeyinwa. See www.lawfirmsinnigeria.com

6 Anon, the poor state of the prisons. www.clearinternational.org downloaded on April 11, 2010

7 The Prison Decongestion Project in Nigeria: An Appraisal by Mbanefo Ifeyinwa. See www.lawfirmsinnigeria.com

8 Ibid

9 Omaka C. A. Assessing justice: A challenge to Nigerian Prison Detainees. Daily Trust, April 4, 2008

10 Detention order under the ruling of a magistrate because the magistrate has no jurisdiction to try the case. This is an aberration as there is no law backing this unfortunate judicial tradition.

11 Ibid

12 Omaka C. A. Assessing justice: A challenge to Nigerian Prison Detainees. Daily Trust, April 4, 2008

13 www.newswatchngr.com op cit

14 The Prison Decongestion Project in Nigeria: An Appraisal by Mbanefo Ifeyinwa. See www.lawfirmsinnigeria.com

15 Ibid

16 Omaka C. A. Assessing justice, op cit p.7 
justice and administration in Nigeria. ${ }^{17}$ Furthermore, the resource noted that inadequate number of judges and magistrates to try cases is also one of the causes of congestion of prisons in Nigeria. They further observed that a situation where the same judge or magistrate handles both criminal and civil cases is no more acceptable in the developed world because it does not make for rapid dispensation of justice. In addition, the forum noted that vehicles conveying awaiting trial detainees to courts are not enough. Added to this as observed by the forum is the constant strike by the judiciary workers thereby keeping detainees in custody for many months without hearing their cases at all ${ }^{18}$.

Another factor identified as one of the causes of prison congestion is the centralisation of the management of Nigerian prisons. ${ }^{19}$ Another factor leading to congestion of prisons in Nigeria is the inadequate number of prisons. It was disclosed at the forum ${ }^{20}$ discussed above that there are 227 prisons in Nigeria, which accommodate over 40,000 inmates. This number is grossly inadequate because if the facilities are inadequate in number and in size, there will be over congestion.

In his contribution on the issue of prison congestion, Prince Olagunsoye Oyinola, Osun State Governor, in the Daily Sun issue of March 16, 2010 implored the judiciary to evolve ways of tackling cases of those awaiting trial across the nation's prisons. Further, Prince Oyinlola observed that the problem of prison congestion was caused by the judicial process and awaiting trial syndrome. According to Chief Bayo Ojo, former Attorney-General of the federation and Minister of Justice, there are 45,000 inmates in our prisons out of which $65 \%$ are awaiting trial. Chief Ojo posited that the problem of over congestion was also occasioned by missing case files among other things.

In a similar vein, Mohammed Fawehinmi, son of human rights activist, Chief Fawehinmi, recently disclosed after his tour of the various prisons in the country that he found about 28,000 awaiting trial inmates (ATI) in our prisons across the country. This corroborates the above disclosure made by the former Federal Attorney-General and Minister for Justice, Chief Bayo Ojo to members of the House of Representatives on October 13, 2005 that there are 25,000 Awaiting Trial Inmates rotting away in various Nigerian prisons. One clear deduction from the disturbing revelations of Fawehinmi and Ojo is that over-congestion in Nigerian prisons is caused by ATI.

In the course of his lecture with final year students of Ebonyi State University, Abakaliki on 18/01/2010, Dr. Okpara Okpara, Human Rights lecturer, maintained that the "holding charge" as used by the police to arrest and detain people without charge is also a cause of prison congestion, as well as violation of citizens' human rights. Contributing still to the cause of prison congestion, Chief Bayo Ojo traced over-congestion to long delays in bringing people to trial.

These shortcomings notwithstanding, Nigeria has not closed its eyes or folded its hands on the problem of congestion as to ameliorate the situation. Many propositions, policies and private opinions have been generated, some applied, in a bid to neutralise the menace of this congestion.

17 A non-governmental organisation at the conference hall of the University of Lagos on how to decongest the heavily congested Nigerian prison. See www.lawfirmsinnigeria.com, op cit

18 Ibid

19 Peter Onu, Prison chaos: what went wrong? Daily Mirror March 6, 2009. Note also that the management of the Nigeria prisons is placed under the exclusive legislative list and therefore being controlled solely by the Federal Government by virtue of the Constitution of the Federal Republic of Nigeria, 1999.

20 "Detainees and Indigent Help Centre", op cit 
In a recent knee-jerk approach to decongest Nigerian Prisons, the 36 Governors have consented to the execution of condemned prisoners. The governors took the decision after debating the challenges posed by prison congestion at the National Economic Council (NEC) meeting in Abuja on April 20th 201021. The decision was sequel to a presentation by the Nigerian Prison Service informing the gathering that the governor's inability to approve the execution of condemned prisoners, in some cases years after their sentences were passed was partly responsible for prison congestion. The problem of congestion is indeed a major challenge in Nigerian prisons, Abakaliki and Afikpo prisons in Ebonyi state are not exceptions. This is a time for action.

\subsection{Statement of the Problem}

From the above background, it is evident that prison congestion and violation of the fundamental human rights of inmates is a challenge to criminal justice administration in Nigeria. Preliminary findings in Abakaliki prison show that it is operating above built capacity; in addition, both Abakaliki and Afikpo prisons have more Awaiting Trial Men (ATM) than convicts. Again, most of the inmates had no legal representation nor access to justice. For example, our preliminary needs assessment findings revealed that 714 inmates were detained in Abakaliki prison whose carrying capacity is a maximum of 387. Following the need to be part of the Federal Government of Nigeria and Development partners, multifaceted approach to prison services and consequent decongestion, we in Ebonyi State University Law Clinic ${ }^{22}$ decided to make prison projects one of her cardinal projects for 2009/2010.

\subsection{Project Objectives}

The purpose of this study is not only geared at assisting the inmates of the two federal prisons in the state to access legal service, but also to avail the pivotal law students an opportunity to work and learn with real live clients, viz the ATI and those wrongly detained. The objectives of the project specifically:

1. To train the clinical law students on the dos and don'ts in prisons, especially in relation to inmates;

2. To identify the precise legal needs of Afikpo and Abakaliki prisons' inmates;

3. To identify the available legal aid facilities presently available to the inmates of the two prisons;

4. To investigate or access the impact of available legal aid, if any, to identify legal needs most imperative to them;

5. To carry out advocacy on the legal aid need of the inmates;

6. To secure bail, and as much as practicable, secure release of the inmates.

21 Prison Congestion: published 28/04/2010-www.thenationonlineng.net

22 Succinctly known as 'EBSU Law Clinic' 


\subsection{Delimitation of the Area of the Project}

The scope of this project will be restricted to the two available prisons in the Ebonyi State, namely:

- Afikpo, and

- Abakaliki prisons.

Incidentally, the areas where the two prisons are located reflect the two political blocs (carved out of Abia (Afikpo) and Enugu (Abakaliki) state) that make up the present Ebonyi State. The project is mainly a research project and also embodies pro bono legal aid.

\subsection{Significance of the Project / Expected Outcome}

It is hoped that this publication would be a useful benchmark and reference point to governments, the United Nations agencies, development partners, researchers and relevant stakeholders $\mathrm{x}$-raying the prevailing conditions in prisons across the country with a view to using the data contained here-in as a basis for strategising on necessary interventions. This would help in improving the physical and mental health of officers and inmates and especially achieving the overall goals of imprisonment as a means of reform and rehabilitation while complying with human rights standards. In addition, if the recommendations are implemented:

- Justice would be more accessible to the detainees/convicts;

- There would be proper identification and categorisation of the legal needs of prison inmates;

- Documentation of the legal needs of prison inmates in Ebonyi state would be easy;

- There would be better understanding of the legal aid needs of the prison detainees;

- The law students would know the role of law clinics in prison projects and be part of the solution through their free legal aid services;

- The law students would learn the law by doing, which will ultimately translate to functional and effective law practices by graduates of EBSU the clinic.

\subsection{Limitations / Challenges of the Prison Project}

The problems encountered in the course of this work include:

1. The difficulty of embarking on this project together with other demanding academic works;

2. The decline of interest in the project by some prison staff;

3. The absence of official EBSU Law Clinic bus;

4. Institutional/in-house administrative delays, bottlenecks and challenges;

5. The protracted ASUU23 strike delayed the projected timing of the project.

23 This acronym means Academic Staff Union of Nigerian Universities. 


\section{Part 2}

\section{RESEARCH METHODOLOGY}

\subsection{Selecting Sample Population}

This research deals with prison decongestion and access to justice. It is not often easy to carry out a study in all the prisons in Nigeria. Consequently, the Abakaliki and Afikpo Federal Prison were selected for study, simply because of accessibility to the two prisons and because they fall within the jurisdiction of EBSU Law Clinic. Not all staff and detainees were interviewed in the two prisons, rather a random sample of the population was selected to be studied. This sample was deemed to be a true and fair representation of the entire population.

\subsection{Research Design}

The research design to be utilised was field survey. ${ }^{24}$ The data collection was done through valid and reliable questionnaires administered to the sample population and personal interviews by the researchers with the controller of the two federal prisons involved in the stress area as well as the wealth of literature that exist helped the researchers to conceptualise the area which served as the basis for the formulation of the questionnaire. The questionnaire was designed in such a way that it contains a blend of fixed alternative questions that are meant to specifically limit the responses of the respondents to specific alternatives and an open ended question that offers the respondents opportunities of expressing their opinions. Again, personal interviews were used to augment information obtained through questionnaire, and in some cases, to assist those who could not read and write.

\subsection{Sample Design}

As at the time of this study there were 227 prisons across the country. Due to time and financial constraints, this research work was specifically carried out in the two federal prisons located in Ebonyi State. In the selected prison, the controllers and the deputy controllers and other principal staff and inmates either responded through questionnaires or were physically interviewed, because of their expert knowledge of the workings of prisons.

\subsection{Instruments of Data Collection}

Primary sources of data on the other hand are sources from which raw data can be obtained. Data or information that were received from the prison staff and detainees constitute the primary data. The following methods were used in the collection of primary data. ${ }^{25}$

24 Ogbazi, J.N., \& Okpala, J. (1994). Writing Research Report: Guide for Researchers in Education, the Social Sciences and Humanities. Enugu: Press Time Ltd.

25 Olaitan, S.O. (1983). Likert research style adopted by author while considering factors associated with nonutilisation of hospital services for antenatal care by pregnant women in rural communities of Anambra State of Nigeria. In O.S. Okobiah, A. Ali \& G.B.I. Onuoha (Eds.), Occasional publication of Institute of Education, University of Nigeria, Nsukka (No. 4, 65-70). Nsukka: Institute of Education, University of Nigeria. 
I. Questionnaire survey - A well structured EPDAFEQ was designed. ${ }^{26}$ The questionnaire survey was the major method of data collection. It was also a basis for opinion assessment. Questions contained in the questionnaire were intended to ascertain the condition of prisoners and access to justice. To achieve the reliability of the data, the questionnaires were administered on the prisoners, together with oral interview. As the prisoners' answer in the interview, their responses in most cases were recorded in the questionnaire. Others interviewed were persons in key positions namely, the Controller, the Deputy Controller and principal staff of the prisons in the stress areas.

II. Interviews - In addition to questionnaires, interviews were used to collect data. This proved effective as it helped the researchers in determining in time the actual scope of the topic that was being studied and the identification of contemporary problems in the management of prisons and accessibility of justice.

III. Observation - During the research process, the researchers examined some documents that relate to the area of study, and the physical condition of the prisons and detainees.

In addition, the researchers found valuable unpublished lectures delivered by individuals with adequate knowledge of the topic. These no doubt are very good sources of secondary data collection. Although this research work is a field one which involves extensive use of communication, observation and interviews, comprehensive review of related literature was made. This derives from primary and secondary sources, communication and observation were based on primary sources while review of related literature was based on secondary source literature which was obtained from various libraries. In order to collect accurate and reliable data, we extensively visited the Abakaliki and Afikpo federal prisons all in Ebonyi State, Nigeria.

\subsection{Modus operandi}

Before the commencement of the research, a pre-field training workshop on the code of conduct in prisons was organised for the researcher and the clinicians. Resource persons included inter alia prison officials and other experts. In addition, advocacy visits were arranged with stakeholders like Nigerian Bar Association, the Attorney General of Ebonyi State and the Prison Authorities. All activities of the clinicians were under the supervision of qualified clinical lawyers.

\section{Part 3}

\section{PRESENTATION AND ANALYSIS OF DATA}

\subsection{Introduction}

During the field work, 227 questionnaires titled "EPDAFEPQ" were distributed and we successfully retrieved information from 222 respondents, while 4 questionnaires were not recovered generally. Two were lost at Abakaliki prisons. Similarly, 65 questionnaires were given to 65 respondents, 63 were recovered, while two were lost. Hence, $98.5 \%$ recovery rate was achieved. We consider the retrieval rate quite impressive. This result in collection of data was made possible by the on-the-

26 Similarly see Ogbazi, J.N., \& Okpala, J. (1994). Writing research report: Guide for researchers in education, the social sciences and humanities. Enugu: Press Time Ltd. 
spot distribution and collection after assisting the respondents in completing the forms.

Tables one to 14 are a presentation of the data from both Abakaliki and Afikpo prisons. While tables 1-7 relate to Abakaliki prisons, tables 8-14 represent findings from Afikpo prisons.

\subsection{ABAKALIKI PRISON - 159 RESPONDENTS}

Table 1: Bio-data of detainees

\begin{tabular}{|c|c|c|c|c|c|}
\hline \multicolumn{2}{|c|}{ Sex } & \multicolumn{2}{c|}{ Age } & \multicolumn{2}{c|}{ Marital status } \\
\hline Men & Women & $\begin{array}{c}\text { Children } \\
\text { below 18 }\end{array}$ & Above 18 & Married & Single \\
\hline 139 & 20 & 4 & 155 & 33 & 126 \\
\hline
\end{tabular}

The above data in Table 1 shows that there are more men than women in Abakaliki prisons. The data in table one reveals as follows: $87.4 \%$ of men and $12.6 \%$ women; Children $2.5 \%$ and adults of 18 years and above $97.5 \%$. It also shows that $20.8 \%$ are married while $79.2 \%$ are single in Abakaliki prisons.

Table 2: Types of detainees and nature of offences

\begin{tabular}{|c|c|c|c|c|c|c|c|c|}
\hline \multicolumn{10}{|c|}{ Nature of Crime } \\
\hline Rape & $\begin{array}{c}\text { Armed } \\
\text { robbery }\end{array}$ & Cultism & Stealing & $\begin{array}{c}\text { Breaking } \\
\text { and entry }\end{array}$ & Arson & Murder & Kidnapping & $\begin{array}{c}\text { Assault and } \\
\text { battery }\end{array}$ \\
\hline 6 & 23 & 7 & 33 & 43 & 4 & 10 & 3 & 30 \\
\hline
\end{tabular}

Table 2 reveals the following percentages on the nature of crime: rape $3.8 \%$, armed robbery $14.5 \%$, cultism $4.4 \%$, stealing $-20.8 \%$, breaking and entry $-27 \%$, arson $-2.5 \%$, murder $-6.3 \%$, kidnapping $-1.8 \%$ and assault and battery $-18.9 \%$.

Table 3: Nature of detention, legal representation and access to justice

\begin{tabular}{|c|c|c|c|c|c|c|c|c|c|c|}
\hline \multicolumn{2}{|c|}{ Nature of detention } & \multicolumn{2}{c|}{$\begin{array}{c}\text { Number of years } \\
\text { detained }\end{array}$} & $\begin{array}{c}\text { Number with legal } \\
\text { representation }\end{array}$ & \multicolumn{2}{c|}{$\begin{array}{c}\text { Delay in } \\
\text { representation/ }\end{array}$} & \multicolumn{2}{c|}{ Recidivists } \\
\hline ATM & Convicted & $\begin{array}{c}\text { Under- } \\
\text { going } \\
\text { trial }\end{array}$ & $\begin{array}{c}\text { Below } \\
\text { one year }\end{array}$ & $\begin{array}{c}\text { Above } \\
\text { one year }\end{array}$ & $\begin{array}{c}\text { I have a } \\
\text { lawyer }\end{array}$ & $\begin{array}{c}\text { I don't } \\
\text { have a } \\
\text { lawyer }\end{array}$ & $\begin{array}{c}\text { There is } \\
\text { speedy } \\
\text { trial }\end{array}$ & $\begin{array}{c}\text { There is } \\
\text { delayed } \\
\text { trial }\end{array}$ & Very few & Many \\
\hline 132 & 20 & 7 & 3 & 156 & 29 & 130 & 1 & 158 & 39 & 120 \\
\hline
\end{tabular}

Table 3 show the following analysis: there are 83\% Awaiting Trial Men (ATM), those properly tried and convicted $-12.6 \%$, those undergoing trial but detained without conviction - $4.4 \%$, detainees below 1 year $-1.9 \%$, those detained for over 1 year without due process of trial $-98.1 \%$, those with legal representation $18.2 \%$, those without legal representation - $81.8 \%$, respondents who believe that there is delayed prosecution $-99.4 \%$, those who 
responded that there is no speedy prosecution $-0.6 \%$, those who say that there are few recidivists $-24.5 \%$ and those who believe that there are many recidivists in detention $-75.5 \%$.

Table 4: Facilities Available - sanitary, toiletry and environmental

\begin{tabular}{|c|c|c|c|c|c|c|c|c|c|c|c|c|c|c|c|c|c|}
\hline \multicolumn{2}{|c|}{ 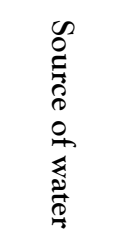 } & \multicolumn{3}{|c|}{ 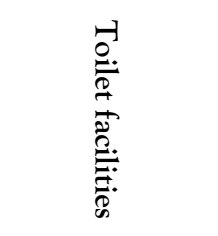 } & \multicolumn{2}{|c|}{ 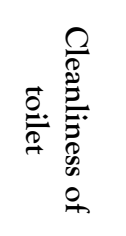 } & \multicolumn{2}{|c|}{ 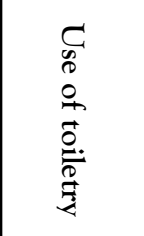 } & \multicolumn{2}{|c|}{ 㝘 } & \multicolumn{3}{|c|}{ 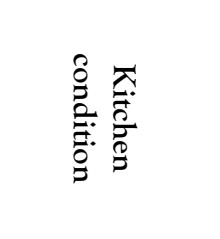 } & \multicolumn{2}{|c|}{ 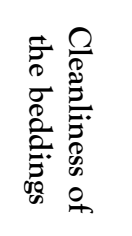 } & \multicolumn{2}{|c|}{ 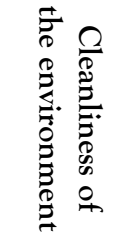 } \\
\hline $\begin{array}{l}0 \\
: \\
\vdots \\
2\end{array}$ & $\begin{array}{l}\mathscr{0} \\
\stackrel{0}{\circ}\end{array}$ & 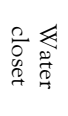 & $\stackrel{ت}{=}$ & $\begin{array}{l}\stackrel{\square}{\tilde{E}} \\
\stackrel{n}{\hat{\pi}} \\
\stackrel{\rightarrow}{\leftrightarrow}\end{array}$ & $\begin{array}{l}\stackrel{\rho}{\overparen{D}} \\
\stackrel{\mathscr{\sigma}}{\sigma}\end{array}$ & $\begin{array}{l}Z \\
0 \\
0 \\
\frac{0}{0} \\
\tilde{g}\end{array}$ & 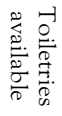 & 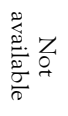 & $\begin{array}{l}\text { T1 } \\
\stackrel{3}{5}\end{array}$ & 莡 & $\frac{2}{\mathscr{8}}$ & 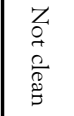 & 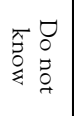 & $\begin{array}{l}\frac{2}{80} \\
\frac{\mathscr{g}}{\mathscr{g}}\end{array}$ & $\begin{array}{l}z \\
0 \\
0 \\
\frac{0}{0} \\
\tilde{g}\end{array}$ & $\stackrel{7}{2}$ & 胥 \\
\hline 60 & 99 & 159 & Nil & Nil & 20 & 139 & 30 & 129 & 121 & 38 & 21 & 128 & 10 & 45 & 114 & 102 & 57 \\
\hline
\end{tabular}

Table 4 shows the following from those interviewed: good water supply $-37.7 \%$, bad water supply $-62.3 \%$; use of water closet $-100 \%$, use of pit toilet $-0 \%$, use of bucket toilet $-0 \%$; the toilets are clean $-12.6 \%$, toilets are messy $-87.4 \%$; toiletries are always available $-18.9 \%$, toiletries not available $-81.1 \%$; I sleep on foam $-76.1 \%$, I sleep on mat $-23.9 \%$; the beddings are clean $28-3 \%$, the beddings are not clean $-71.7 \%$; the kitchen is clean $-13.2 \%$, the kitchen is not clean $80.5 \%$, no idea whether clean or not clean $-6.3 \%$; cleanliness of the prison environment $-64.2 \%$, there is untidy environment $-35.8 \%$.

Table 5: Facilities Available - power and healthcare facilities

\begin{tabular}{|c|c|c|c|c|c|c|c|c|c|c|c|c|}
\hline \multicolumn{2}{|c|}{ 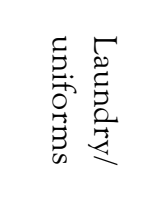 } & \multicolumn{3}{|c|}{ 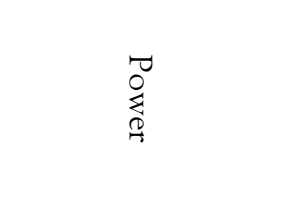 } & \multicolumn{2}{|c|}{ 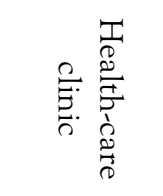 } & \multicolumn{2}{|c|}{ 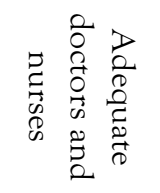 } & \multicolumn{2}{|c|}{$\underset{\substack { D \\
\begin{subarray}{c}{0 \\
\infty{ D \\
\begin{subarray} { c } { 0 \\
\infty } }\end{subarray}}{\forall}$} & \multicolumn{2}{|c|}{ 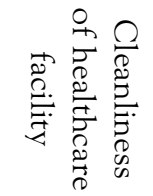 } \\
\hline $\begin{array}{l}0 \\
8 \\
8\end{array}$ & $\begin{array}{l}\text { पूळ } \\
\stackrel{0}{2}\end{array}$ & $\begin{array}{l}\overrightarrow{\widetilde{Z}} \\
\vec{z}\end{array}$ & 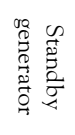 & 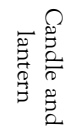 & $\overparen{\&}$ & Z & 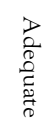 & 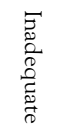 & 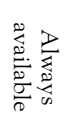 & 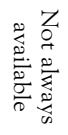 & $\frac{2}{\mathscr{8}}$ & $\begin{array}{l}z \\
0 \\
0 \\
\frac{D}{D} \\
\tilde{g}\end{array}$ \\
\hline 77 & 82 & 159 & Nil & Nil & 150 & 9 & 69 & 90 & 40 & 119 & 125 & 34 \\
\hline
\end{tabular}

Table 5 shows the following responses: good laundry and uniforms $-48-4 \%$, bad laundry and uniforms $-51.6 \%$; sole dependence on epileptic power supply $-100 \%$, standby generator $-0 \%$; clinic available $-95 \%$, clinic not available $-5 \%$; there are adequate doctors and nurses $-43.4 \%$, there are inadequate doctors and nurses $-56.6 \%$; availability of drugs $-25.2 \%$, dearth of drugs $74.8 \%$; clinic and health care facility is clean $-78.6 \%$, filthy health care facility $-21.4 \%$. 
Table 6: Facilities Available - conscience, sporting and recreation

\begin{tabular}{|c|c|c|c|c|c|c|c|c|c|c|c|}
\hline \multicolumn{2}{|c|}{ 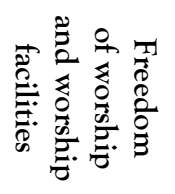 } & \multicolumn{3}{|c|}{ 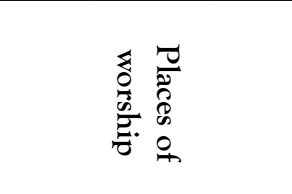 } & \multicolumn{2}{|c|}{ 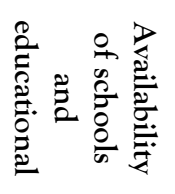 } & \multicolumn{2}{|c|}{ 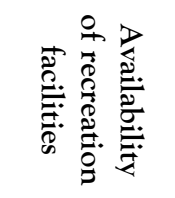 } & \multicolumn{3}{|c|}{ 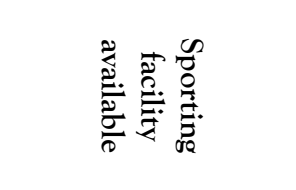 } \\
\hline 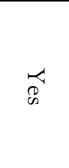 & $z$ & 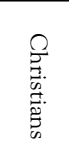 & $\begin{array}{l}z \\
0 \\
0 \\
\frac{n}{0} \\
\vec{s} \\
\omega\end{array}$ & 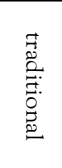 & 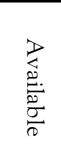 & 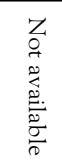 & 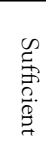 & 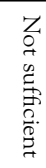 & 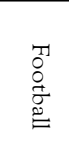 & 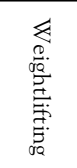 & 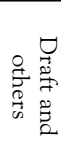 \\
\hline 147 & 12 & 136 & 23 & $\mathrm{Nil}$ & 159 & Nil & 90 & 69 & 159 & 159 & 107 \\
\hline
\end{tabular}

On conscience, sports and recreation, table 6 shows the following line of response: freedom of worship $-92.5 \%$, no freedom of worship $-7-5 \%$; Christians place of worship $-85.5 \%$, availability of Islamic place of worship $-14.5 \%$, traditional place of worship - $0 \%$; availability of school in the prison $-100 \%$ and none said that there is no school. There is sufficiency of recreational facilities $-56.6 \%$, insufficiency of recreational facilities $-43.4 \%$; availability of football facility $-100 \%$, availability of weight lifting facility $-100 \%$; Draft, chess, monopoly, scrabble and other indoors facility $-67.3 \%$, no other sporting availability $-32.7 \%$.

Table 7: availability of vocational facilities

\begin{tabular}{|c|c|c|c|c|c|c|c|c|}
\hline 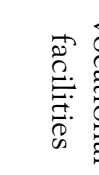 & 胥 & 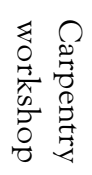 & 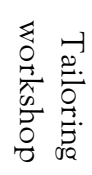 & 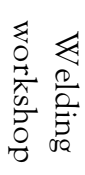 & 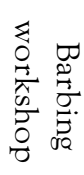 & 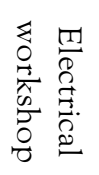 & 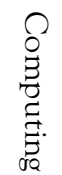 & 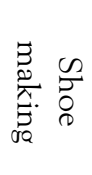 \\
\hline Adequate & Not adequate & \multirow{2}{*}{159} & \multirow{2}{*}{159} & \multirow{2}{*}{159} & \multirow{2}{*}{159} & \multirow{2}{*}{159} & \multirow{2}{*}{159} & \multirow{2}{*}{159} \\
\hline 54 & 105 & & & & & & & \\
\hline
\end{tabular}

Table 7 shows that $66 \%$ of the respondents agree that there are adequate vocational facility while $34 \%$ said that there are not enough vocational facility. $100 \%$ of the respondents said that the following workshops are available in Abakaliki prisons - carpentry, tailoring, barbing, welding, electrical, computing and shoe making workshops. 


\subsection{AFIKPO PRISONS - 63 RESPONDENTS}

Table 8: Bio-data of detainees

\begin{tabular}{|c|c|c|c|c|c|}
\hline Sex & & Age & & Marital status & \\
\hline Men & Women & $\begin{array}{c}\text { Children } \\
\text { below 18 }\end{array}$ & Above 18 & Married & Single \\
\hline 52 & 11 & 4 & 59 & 18 & 45 \\
\hline
\end{tabular}

Table 8 shows that following in relation to Afikpo prisons: men $-82.5 \%$, women $-17.5 \%$; children $-6.3 \%$, adults above 18 years $-93.7 \%$; married prison inmates $-28.6 \%$, single $-71.4 \%$.

Table 9: Types of detainees and nature of offences

\begin{tabular}{|c|c|c|c|c|c|c|c|c|}
\hline \multicolumn{1}{|c|}{ Nature of Crime } \\
\hline Rape & $\begin{array}{c}\text { Armed } \\
\text { robbery }\end{array}$ & Cultism & Stealing & $\begin{array}{c}\text { Breaking } \\
\text { and entry }\end{array}$ & Arson & Murder & Kidnapping & $\begin{array}{c}\text { Assault and } \\
\text { battery }\end{array}$ \\
\hline 2 & 5 & 2 & 21 & 13 & 4 & 4 & 3 & 9 \\
\hline
\end{tabular}

On nature and character of offences upon which detention is based, table 9 reveal as follows: rape $-3.2 \%$, armed robbery $-7.9 \%$, cultism $-3.2 \%$, stealing $-33.3 \%$, breaking and entry $-20.6 \%$, arson $-6.3 \%$, murder $-6.3 \%$, kidnapping $-4.8 \%$, assault and battery $-14.3 \%$.

Table 10: Nature of detention, legal representation and access to justice

\begin{tabular}{|c|c|c|c|c|c|c|c|c|c|c|}
\hline \multicolumn{2}{|c|}{ Nature of detention } & \multicolumn{2}{c|}{$\begin{array}{c}\text { Number of years } \\
\text { detained }\end{array}$} & \multicolumn{2}{c|}{$\begin{array}{c}\text { Number with legal } \\
\text { representation }\end{array}$} & \multicolumn{2}{c|}{$\begin{array}{c}\text { Delay in } \\
\text { representation/ }\end{array}$} & \multicolumn{2}{c|}{ Recidivists } \\
\hline ATM & Convicted & $\begin{array}{c}\text { Under- } \\
\text { going } \\
\text { trial }\end{array}$ & $\begin{array}{c}\text { Below } \\
\text { one year }\end{array}$ & $\begin{array}{c}\text { Above } \\
\text { one year }\end{array}$ & $\begin{array}{c}\text { I have a } \\
\text { lawyer }\end{array}$ & $\begin{array}{c}\text { I don't } \\
\text { have a } \\
\text { lawyer }\end{array}$ & $\begin{array}{c}\text { There is } \\
\text { speedy } \\
\text { trial }\end{array}$ & $\begin{array}{c}\text { There is } \\
\text { delayed } \\
\text { trial }\end{array}$ & Very few & Many \\
\hline 48 & 8 & 7 & 3 & 60 & 7 & 56 & 1 & 62 & 30 & 33 \\
\hline
\end{tabular}

On access to justice and legal representation table 10 shows as follows: those awaiting trial and not convicted $-76.2 \%$, the convicted $-12.7 \%$ and those undergoing trial $-11.1 \%$. Those detained below 1 year $-4.8 \%$. Those above 1 year in detention $-95.2 \%$. Those with legal representation $-11.1 \%$ and those without legal representation $-88.9 \%$. Delayed prosecution $-98.4 \%$, speedy prosecution $-1.6 \%$. Few recidivists $-24.5 \%$ and $75.5 \%$ said there are many recidivists in Afikpo prison. 
Table 11: Facilities Available - sanitary, toiletry and environmental

\begin{tabular}{|c|c|c|c|c|c|c|c|c|c|c|c|c|c|c|c|c|c|}
\hline \multicolumn{2}{|c|}{ 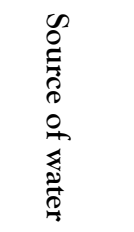 } & \multicolumn{3}{|c|}{ 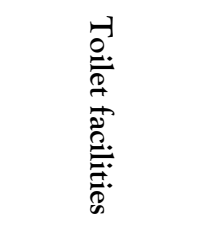 } & \multicolumn{2}{|c|}{ 할. } & \multicolumn{2}{|c|}{$\begin{array}{l}c \\
0 \\
0 \\
0 \\
0 \\
\overrightarrow{0} \\
\overrightarrow{0} \\
0 \\
\vec{b}\end{array}$} & \multicolumn{2}{|c|}{ 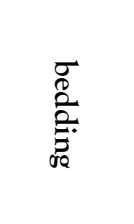 } & \multicolumn{3}{|c|}{ 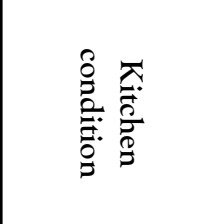 } & \multicolumn{2}{|c|}{ 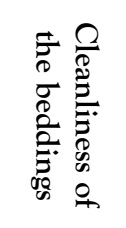 } & \multicolumn{2}{|c|}{ 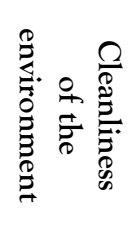 } \\
\hline $\begin{array}{l}0 \\
: \\
: \\
0\end{array}$ & 啹 & 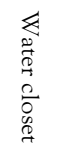 & $\rightleftarrows$ & 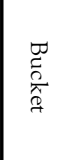 & $\frac{\Omega}{\mathbb{2}}$ & $\begin{array}{l}z \\
0 \\
0 \\
\frac{D}{d} \\
\tilde{B}\end{array}$ & 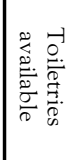 & 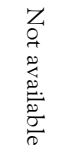 & 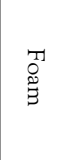 & $\underset{z}{z}$ & $\frac{0}{\mathscr{D}}$ & $\begin{array}{l}Z \\
0 \\
0 \\
\bar{O} \\
\tilde{g}\end{array}$ & 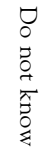 & $\frac{\Omega}{\stackrel{\mathscr{E}}{\tilde{g}}}$ & 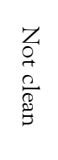 & $\vec{t}$ & $\begin{array}{l}g \\
\stackrel{g}{q}\end{array}$ \\
\hline 9 & 54 & 59 & 4 & $\mathrm{Nil}$ & 18 & 45 & 17 & 46 & 50 & 13 & 20 & 40 & 3 & 20 & 43 & 34 & 29 \\
\hline
\end{tabular}

Table 11 shows the following in relation to sanitary, toiletry and environmental condition of Afikpo prison. Good water supply $-14.3 \%$. Bad water supply $-85.7 \%$. Use of water closet lavatory $-93.7 \%$. Use of pit toilet $-6.3 \%$. Use of bucket toilet $-0 \%$. The toilets are clean $28.6 \%$. The toilets are unkempt $-71.4 \%$. Toiletries are always available $-27 \%$. Toiletries not available $-73 \%$. There is foam to sleep on $-79.4 \%$. I sleep on mat or poorly improvised beddings $-20.6 \%$. Cleanliness of the beddings $-31.7 \%$. Beddings not clean $-68.3 \%$. Kitchen is clean $31.72 \%$. Kitchen is not clean $-63.5 \%$. No idea whether kitchen is clean or not $-4.8 \%$. Cleanliness of environment $-54 \%$ and untidy environment $-46 \%$.

Table 12: Facilities Available - power and healthcare facilities

\begin{tabular}{|c|c|c|c|c|c|c|c|c|c|c|c|c|}
\hline \multicolumn{2}{|c|}{ 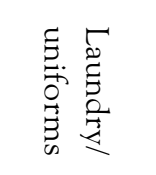 } & \multicolumn{3}{|c|}{ 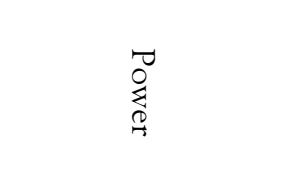 } & \multicolumn{2}{|c|}{ 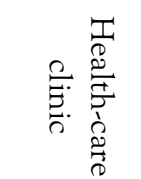 } & \multicolumn{2}{|c|}{ 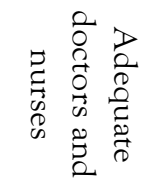 } & \multicolumn{2}{|c|}{$\underset{\substack{\mathbb{Z} \\
0.0 \\
\infty}}{\nabla}$} & \multicolumn{2}{|c|}{ 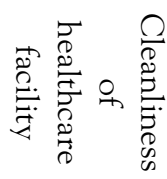 } \\
\hline $\begin{array}{l}8 \\
: \\
:\end{array}$ & 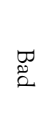 & 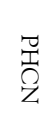 & 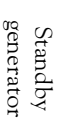 & 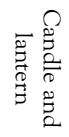 & 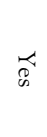 & z & 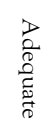 & 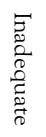 & 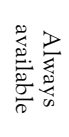 & 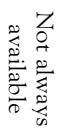 & $\frac{\Omega}{\mathscr{E}}$ & $\begin{array}{l}z \\
0 \\
0 \\
\frac{0}{0} \\
\tilde{B}\end{array}$ \\
\hline 32 & 31 & 63 & Nil & 63 & 54 & 9 & 10 & 53 & 20 & 43 & 32 & 31 \\
\hline
\end{tabular}

Table 12 reveals the following in relation to power and healthcare: good laundry and uniforms $-50.8 \%$, bad laundry and uniforms $-49.2 \%$. Sole dependence on public epileptic power supply$100 \%$. Standby generator $-0 \%$. Clinic available $-93 \%$ and $7 \%$ said no healthcare facility. Adequate doctors and nurses $-15.9 \%$. Inadequate doctors and nurses $-84.1 \%$. Availability of drugs $-31.7 \%$. Dearth of drugs $-68.3 \%$. On whether or not clinic is clean, $50.8 \%$ said yes, while $49.2 \%$ said no. 
Table 13: Facilities Available - conscience, sporting and recreation

\begin{tabular}{|c|c|c|c|c|c|c|c|c|c|c|c|}
\hline \multicolumn{2}{|c|}{ 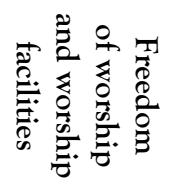 } & \multicolumn{3}{|c|}{ 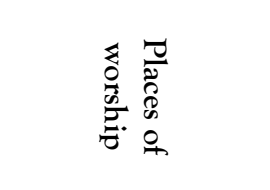 } & \multicolumn{2}{|c|}{ 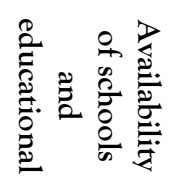 } & \multicolumn{2}{|c|}{ 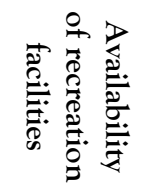 } & \multicolumn{3}{|c|}{ 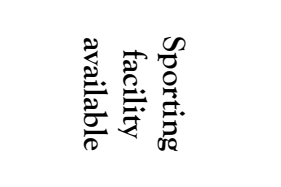 } \\
\hline$\underset{\varnothing}{\overparen{\sigma}}$ & $z$ & 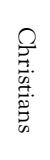 & $\begin{array}{l}z \\
0 \\
0 \\
\frac{m}{0} \\
\vec{s} \\
w\end{array}$ & 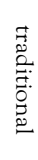 & 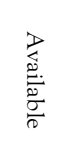 & 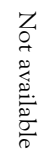 & 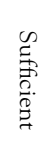 & 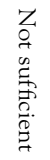 & $\begin{array}{l}0^{T} \\
0 \\
\stackrel{0}{0} \\
\stackrel{\mathscr{E}}{=}\end{array}$ & 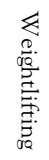 & 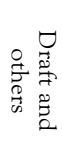 \\
\hline 57 & 6 & 58 & 3 & 2 & Nil & 63 & 25 & 38 & 34 & 15 & 14 \\
\hline
\end{tabular}

Table 13 discloses as follows: there is freedom of worship $-90.5 \%$. No freedom of worship $9.5 \%$. Availability of Christian place of worship $-92.1 \%$. Availability of Islamic place of worship $-4.8 \%$. Traditional religion $-3.1 \%$. on availability of schools, $100 \%$ said no school, while $0 \%$ responded in the positive. Are there sufficiency of recreational facilities $-39.7 \%$ said yes, while $60.3 \%$ said no. On availability of football facility $-50 \%$ said yes, availability of weight lifting facility $-20 \%$ said yes, draft and others $-20 \%$, while $10 \%$ said there are no other sporting facility.

Table 14: availability of vocational facilities

\begin{tabular}{|c|c|c|c|c|c|c|c|c|}
\hline \multicolumn{2}{|c|}{ 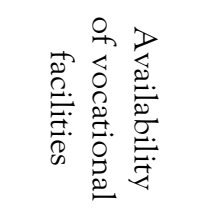 } & 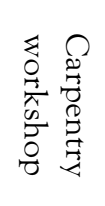 & 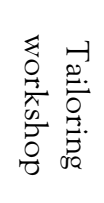 & 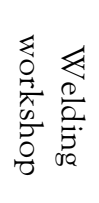 & 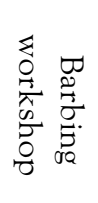 & 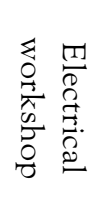 & 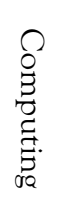 & 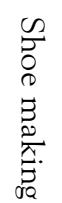 \\
\hline $\begin{array}{l}\vec{D} \\
2 \\
0 \\
0 \\
\overrightarrow{0} \\
\overrightarrow{0} \\
0\end{array}$ & 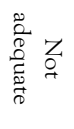 & 63 & 63 & Nil & Nil & Nil & Nil & Nil \\
\hline 31 & 32 & & & & & & & \\
\hline
\end{tabular}

Table 14 shows that in Afikpo prisons 49.2\% said that there are adequate vocational facility, while 50.8 responded that the vocational facilities are inadequate. While $100 \%$ responded that the prison has carpentry and tailoring workshops, they however wished that they had in addition a barbing, welding, computer and shoemaking workshops, which is presently absent in Afikpo prisons. 


\subsection{SUMMARY OF ANALYSIS OF DATA FROM TABLES 1 TO 14 IN PERCENTAGES}

\begin{tabular}{|c|c|c|c|c|}
\hline & Abakaliki & Afikpo & Average & Remark \\
\hline \multicolumn{5}{|c|}{ Tables 1 and 8: Biodata of detainees } \\
\hline Men & 87.4 & 82.5 & 84.95 & \\
\hline Women & 12.6 & 17.5 & 15.05 & \\
\hline Children & 2.5 & 6.3 & 4.4 & Against minimum standards \\
\hline Adult & 97.5 & 93.7 & 95.6 & \\
\hline Married & 20.8 & 28.6 & 24.7 & \\
\hline Single & 79.2 & 71.4 & 75.3 & Crime and youthfulness \\
\hline \multicolumn{5}{|c|}{ Tables 2 and 9: Nature of offences of detainees } \\
\hline Rape & 3.8 & $3.2 \%$ & 3.5 & \\
\hline Armed robbery & 14.5 & $7.9 \%$ & 11.2 & \\
\hline Cultism & 4.4 & $3.2 \%$ & 3.8 & \\
\hline Stealing & 20.8 & $33.3 \%$ & 27.05 & Highest crime rate \\
\hline Breaking and entry & 27 & $20.6 \%$ & 23.8 & \\
\hline Arson & 2.5 & $6.3 \%$ & 4.4 & \\
\hline Murder & 6.3 & $6.3 \%$ & 6.3 & \\
\hline Kidnapping & 1.8 & $4.8 \%$ & 3.3 & $\begin{array}{l}\text { Emerging crime since } 2008 \\
\text { particularly in South Eastern } \\
\text { Nigeria }\end{array}$ \\
\hline Assault and battery & 18.9 & $14.3 \%$ & 16.6 & \\
\hline
\end{tabular}




\begin{tabular}{|c|c|c|c|c|}
\hline & Abakaliki & Afikpo & Average & Remark \\
\hline \multicolumn{5}{|c|}{ Tables 3 and 10: Nature of detention, legal representation and access to justice } \\
\hline $\begin{array}{l}\text { ATM (Awaiting } \\
\text { Trial Men) }\end{array}$ & $83 \%$ & $76.2 \%$ & $79.6 \%$ & $\begin{array}{l}\text { Imprisonment without trial is } \\
\text { unacceptable }\end{array}$ \\
\hline Convicted & $12.6 \%$ & $12.7 \%$ & $12.65 \%$ & Low \\
\hline Undergoing trial & $4.4 \%$ & $11.1 \%$ & $7.75 \%$ & $\begin{array}{l}\text { Unacceptable: lack of access } \\
\text { to justice }\end{array}$ \\
\hline $\begin{array}{l}\text { Detained below } 1 \\
\text { year }\end{array}$ & $1.9 \%$ & $4.8 \%$ & $3.35 \%$ & Low \\
\hline Above 1 year & $98.1 \%$ & $95.2 \%$ & $96.65 \%$ & $\begin{array}{l}\text { High and unacceptable: access } \\
\text { to justice }\end{array}$ \\
\hline Those with lawyers & $18.2 \%$ & $11.1 \%$ & $14.65 \%$ & Poor access to justice \\
\hline $\begin{array}{l}\text { Without legal } \\
\text { representation }\end{array}$ & $81.8 \%$ & $88.9 \%$ & $85.35 \%$ & Lack of access to justice \\
\hline $\begin{array}{l}\text { Delayed } \\
\text { prosecution }\end{array}$ & $99.4 \%$ & $98.4 \%$ & $99 \%$ & $\begin{array}{l}\text { Delay in criminal justice } \\
\text { delivery }\end{array}$ \\
\hline Speedy prosecution & $0.6 \%$ & $1.6 \%$ & $1.1 \%$ & Poor \\
\hline Few recidivists & $24.5 \%$ & $24.5 \%$ & $24.5 \%$ & \\
\hline Many recidivists & $75.5 \%$ & $75.5 \%$ & $75.5 \%$ & Recidivism: a bad omen \\
\hline \multicolumn{5}{|c|}{ Tables 4 and 11: Facilities Available - sanitary, toiletry and environmental } \\
\hline Good water supply & $37.7 \%$ & $47.6 \%$ & $42.65 \%$ & \\
\hline Bad water supply & $62.3 \%$ & $52.4 \%$ & $57.35 \%$ & A problem \\
\hline Water closet toilet & $100 \%$ & $93.7 \%$ & $96.85 \%$ & Good \\
\hline Pit toilet & $0 \%$ & $6.3 \%$ & $3.15 \%$ & \\
\hline Bucket & $0 \%$ & $0 \%$ & $0 \%$ & \\
\hline Clean toilet & $12.6 \%$ & $28.6 \%$ & $20.6 \%$ & \\
\hline Not clean & $87.4 \%$ & $71.4 \%$ & $79.4 \%$ & A problem \\
\hline $\begin{array}{l}\text { Toiletries are } \\
\text { always available }\end{array}$ & $18.9 \%$ & $27 \%$ & $22.95 \%$ & \\
\hline $\begin{array}{l}\text { Toiletries not } \\
\text { available }\end{array}$ & $81.1 \%$ & $73 \%$ & $77.05 \%$ & A problem \\
\hline I sleep on foam & $76.1 \%$ & $79.4 \%$ & $77.75 \%$ & \\
\hline I sleep on mat & $23.9 \%$ & $20.6 \%$ & $22.25 \%$ & $\mathrm{Bad}$ \\
\hline $\begin{array}{l}\text { Cleanliness of the } \\
\text { beddings }\end{array}$ & $28.3 \%$ & $31.7 \%$ & $30 \%$ & \\
\hline Beddings not clean & $71.7 \%$ & $68.3 \%$ & $70 \%$ & A problem \\
\hline Kitchen is clean & $13.2 \%$ & $31.72 \%$ & $22.46 \%$ & \\
\hline
\end{tabular}




\begin{tabular}{|c|c|c|c|c|}
\hline & Abakaliki & Afikpo & Average & Remark \\
\hline Not clean & $80.5 \%$ & $63.5 \%$ & $72 \%$ & A problem \\
\hline I don't know & $6.3 \%$ & $4.8 \%$ & & \\
\hline $\begin{array}{l}\text { Cleanliness of } \\
\text { environment }\end{array}$ & $64.2 \%$ & $54 \%$ & $59.1 \%$ & \\
\hline $\begin{array}{l}\text { Untidy } \\
\text { environment }\end{array}$ & $35.8 \%$ & $46 \%$ & $41 \%$ & Not good enough \\
\hline \multicolumn{5}{|c|}{ Tables 5 and 12: Facilities Available - power and healthcare facilities } \\
\hline $\begin{array}{l}\text { Good laundry and } \\
\text { uniforms }\end{array}$ & $48.4 \%$ & $50.8 \%$ & $49.6 \%$ & Just for the convicted \\
\hline $\begin{array}{l}\text { Bad laundry and } \\
\text { uniforms }\end{array}$ & $51.6 \%$ & $49.2 \%$ & $50.4 \%$ & \\
\hline $\begin{array}{l}\text { Sole dependence } \\
\text { on epileptic power } \\
\text { supply }\end{array}$ & $100 \%$ & $100 \%$ & $100 \%$ & A problem \\
\hline Standby generator & $0 \%$ & $0 \%$ & $0 \%$ & \\
\hline Clinic available & $93 \%$ & $95 \%$ & $94 \%$ & Good \\
\hline Clinic not available & $7 \%$ & $5 \%$ & $6 \%$ & \\
\hline $\begin{array}{l}\text { Adequate doctors } \\
\text { and nurses }\end{array}$ & $43.4 \%$ & $15.9 \%$ & $29.65 \%$ & \\
\hline $\begin{array}{l}\text { Inadequate doctors } \\
\text { and nurses }\end{array}$ & $56.6 \%$ & $84.1 \%$ & $70.35 \%$ & A problem \\
\hline $\begin{array}{l}\text { Availability of } \\
\text { drugs }\end{array}$ & $25.2 \%$ & $31.7 \%$ & $28.45 \%$ & \\
\hline Dearth of drugs & $74.8 \%$ & $68.3 \%$ & $71.55 \%$ & A problem \\
\hline Clinic is clean & $78.6 \%$ & $50.8 \%$ & $64.7 \%$ & A problem \\
\hline Not clean & $21.4 \%$ & $49.2 \%$ & & \\
\hline
\end{tabular}




\begin{tabular}{|c|c|c|c|c|}
\hline & Abakaliki & Afikpo & Average & Remark \\
\hline \multicolumn{5}{|c|}{ Tables 6 and 13: Facilities Available - conscience, sporting and recreation } \\
\hline $\begin{array}{l}\text { Freedom of } \\
\text { worship }\end{array}$ & $92.5 \%$ & $90.5 \%$ & $91.5 \%$ & Good \\
\hline $\begin{array}{l}\text { No freedom of } \\
\text { worship }\end{array}$ & $7.5 \%$ & $9.5 \%$ & $8.5 \%$ & \\
\hline Christians & $85.5 \%$ & $92.1 \%$ & $89 \%$ & \\
\hline Moslems & $14.5 \%$ & $4.8 \%$ & $9.65 \%$ & \\
\hline Traditional religion & $0 \%$ & $3.1 \%$ & $1.55 \%$ & \\
\hline School available & $100 \%$ & $0 \%$ & $\mathrm{~N} / \mathrm{A}$ & Good \\
\hline Not available & $0 \%$ & $100 \%$ & $\mathrm{~N} / \mathrm{A}$ & A problem \\
\hline $\begin{array}{l}\text { Sufficiency of } \\
\text { recreational } \\
\text { facilities }\end{array}$ & $56.6 \%$ & $39.7 \%$ & $48.15 \%$ & Fair \\
\hline Not sufficient & $43.4 \%$ & $60.3 \%$ & $51.85 \%$ & \\
\hline $\begin{array}{l}\text { Availability of } \\
\text { football facility }\end{array}$ & $100 \%$ & $50 \%$ & $75 \%$ & Good \\
\hline $\begin{array}{l}\text { Availability of } \\
\text { weight lifting } \\
\text { facility }\end{array}$ & $100 \%$ & $20 \%$ & $60 \%$ & Good \\
\hline $\begin{array}{l}\text { Draft, chess, } \\
\text { monopoly, scrabble } \\
\text { and others }\end{array}$ & $67.3 \%$ & $20 \%$ & $43.65 \%$ & Not good enough \\
\hline $\begin{array}{l}\text { No other sporting } \\
\text { availability }\end{array}$ & $32.7 \%$ & $10 \%$ & $21.35 \%$ & \\
\hline \multicolumn{5}{|c|}{ Tables 7 and 14: Availability of vocational facilities } \\
\hline $\begin{array}{l}\text { Adequate } \\
\text { vocational facility }\end{array}$ & $66 \%$ & $49.2 \%$ & $57.6 \%$ & Fair \\
\hline Not adequate & $34 \%$ & $50.8 \%$ & $42.4 \%$ & \\
\hline Carpentry & $100 \%$ & $100 \%$ & $100 \%$ & Good \\
\hline Tailoring & $100 \%$ & $100 \%$ & $100 \%$ & Good \\
\hline Barbing & $100 \%$ & 0 & N/A & Good/Bad \\
\hline Welding & $100 \%$ & 0 & $\mathrm{~N} / \mathrm{A}$ & Good/Bad \\
\hline Electrical & $100 \%$ & 0 & N/A & Good/Bad \\
\hline Computing & $100 \%$ & 0 & N/A & Good/Bad \\
\hline Shoemaking & $100 \%$ & 0 & $\mathrm{~N} / \mathrm{A}$ & Good/Bad \\
\hline
\end{tabular}




\section{Part 4}

\section{SUMMARY OF FINDINGS}

1. After fact finding visits to the two federal prisons in Ebonyi State of Nigeria, we discovered that we have 914 detainees/convicts in prisons for which capacity is 387 .

2. Afikpo prison is operating within the built capacity by having 162 inmates with capacity of 200.

3. In Afikpo 138 are awaiting trial (ATM), while only 24 are serving their terms after proper court conviction.

4. In Abakaliki prison 848 detainees are awaiting trial, while only 66 are serving their terms after proper court conviction.

5. Out of 269 inmates so far interviewed directly or via a questionnaire in both Abakaliki and Afikpo prisons only 65 agreed that they have access to justice, while 204 have no counsel representing them, despite the supposed Federal Government of Nigeria Prison Decongestion Programme.

6. Out of these 269 , only 65 are presently going on in court. The rest were merely charged and detained without more.

7. According to our findings, they were remanded because the magistrates courts where they where charged under 'holding charge' had no jurisdiction.

8. There were cases which were sent to the Director of Public Prosecution (DPP) for advice. The advice has either not been given, or the DPP was yet to put their papers together for information or charge to be brought to High Courts of competent jurisdiction.

9. Afikpo prison is generally old, the facility old, obsolete and overdue for repairs or replacement. In both Abakaliki and Afikpo prisons, basic facilities were either inadequate or totally lacking. For example, both Afikpo and Abakaliki prisons have no functional standby generator, and water is a major challenge. Irregular water and power supply in the prisons reflected the general situation in the country. Most prisons had no alternative source of power while water supply was irregular and inadequate.

10. Although recreational facilities, like football and weightlifting are available in Abakaliki, they are grossly inadequate; and completely unavailable in the Afikpo prisons. Both prisons need well established facilities for recreation, like football, basket ball, lane tennis, table tennis and indoor games like monopoly, scrabble, draft, chess etc.

11. There was general unavailability of drugs, medical personnel and equipment in the prisons. Only one doctor serves both Afikpo and Abakaliki, and none has resident doctors. Afikpo prison, for example has only a doctor who visited occasionally from Abakaliki. The prisons did not have the facility to handle psychiatric and ante-natal cases.

12. Transport facilities were grossly inadequate in the two prisons. The prisons need more Green Maria, mini vans, pick-up trucks and ambulances.

13. While Abakaliki prison has a modest computer room for inmates, mini-library and classrooms where inmates receive primary and secondary education and are subsequently 
registered for external examinations, however, this facility is lacking at Afikpo prison. There is no school or library facility nor do they have a computer room or any educational facilities at all at Afikpo prison.

14. Abakaliki prison have provision for vocational training in one form or the other. For example, at Abakaliki there are tailoring, electrical, barbing, welding and carpentry workshops, where the trades and vocations are taught in the prison. To the contrary these vocational facilities are absent in Afikpo prison, apart from tailoring and carpentry workshops. Although the inmates at Afikpo are interested in barbing, shoe making and computing, there were no such facilities. Even at Abakaliki where most of the vocational equipment existed, the workshops were ill-equipped with obsolete tools and lacked trained instructors.

15. Like in most prisons in urban areas, there was overcrowding in prisons in Abakaliki prison, with over hundred percent extra detainees; while Afikpo prison operates within built capacity.

16. The state of the cells was poor and hardly fit for human habitation. This was especially so in the awaiting trial cells. Ventilation was poor due to overcrowding. The poor state of the toilets in the cells contributed to the deplorable condition of the cells thereby posing health risks to inmates.

17. Beds and beddings were generally inadequate with many inmates having to sleep on improvised mats and beddings in both prisons.

18. Many inmates had no uniforms. The few uniforms available were old and thread-bare.

19. Feeding in both prisons were thrice in most cases, but not well made and balanced. The prisoners said that the quantity and quality was highly poor and unacceptable. Some of the prisoners, especially at Abakaliki commented that feeding was generally poor even though it was three times a day (but not all days).

20. Residential accommodation for prison officers was virtually non-existent in both Afikpo and Abakaliki prisons. Where they existed, it was grossly inadequate. Office accommodation was also inadequate and more often than not, dilapidated. Office equipment such as file cabinets, computers, photocopiers amongst others, were also not available. Communication and security equipment were also lacking. Chairs and tables were old and needed replacement.

21. It was difficult to obtain records of inmates with legal representation, inmates whose case files were missing, and those whose cases were stalled on account of unavailability of the Investigating Police Officer (IPO) and advice from the DPP. This was because of poor record keeping system in the prisons. Most records in this regard, were obtained through direct interviews with the inmates.

22. Legal representation was generally low in both Afikpo and Abakaliki prisons visited. There were many persons awaiting trial who did not have legal representation. Although some prisons did benefit from the Federal Government's prison decongestion exercise, many prisons did not have records of this exercise to assess its impact. It was also observed that the Federal Government Decongestion exercise, especially assignment of cases to private law firms, concentrated on prisons in urban centres, and in any case was very selective, as over $90 \%$ had no access to justice.

23. There were no facilities for the care of pregnant women or nursing mothers in the prisons. Children born in prison were kept with their mothers until they were weaned. No extra 
provision was made for the care of such babies.

24. Although very few, children were found in some of the prisons visited. Three children were seen at Abakaliki and one at Afikpo. No special provisions were made for children as this was not a consideration for classification and separation of inmates in the prisons.

25. There were inmates with life threatening ailments in the prisons visited. Such ailments include tuberculosis, HIV/AIDS, cancer, amongst others. 9 of such cases were seen in Abakaliki and 6 in Afikpo prison. Though the clinics were not equipped to handle complex cases like these, there was provision of drugs for some of the ailments like tuberculosis. The anti retroviral drugs for HIV/AIDS were available but were not supplied regularly. Cases involving surgery were referred to the general hospitals. Skin diseases like eczema and ringworm were a common place in both prisons.

26. 12 lunatics were seen at Abakaliki prisons. It should be noted that lunatics require special care and should not to be kept in the prison where there are no facilities for their care and treatment.

\section{State of Afikpo Prison}

27. On the state of the prisons, we discovered that Afikpo federal prison is one of the oldest in the country. It was built by colonial masters as far back as 1911.

28. It is one of the first 20 out of the over 227 prisons in Nigeria.

29. Not surprisingly therefore, the environment is very untidy with dilapidated structures mainly made of asbestos

30. It has not had any significant renovation since its inception about 100 years ago.

\section{State of Abakaliki Prison}

31. It was built by the colonial administration in 1946 .

32. Although the compound outwardly appears neater than the Afikpo prison, the cells are not as neat.

33. The cells may have been left unkempt possibly to deter recidivists from contemplating a comeback.

34. Like the Afikpo prison, no significant renovation has taken place since its construction 63 years ago.

35. Again, open interviews randomly done during the course of our prison outreach programmes revealed as follows:

- Out of 222 detainees interviewed, only 20 representing about $8 \%$ of the population studied agreed that they had access to justice and can afford a lawyer.

- $93 \%$ said that they often concede their legal rights because they can't afford the services of a lawyer.

- Some said that many times they don't even know when their legal rights are denied them or infringed on. 


\section{Part 5}

\subsection{RECOMMENDATIONS AND CONCLUSION}

We recommend that Federal and State Government, the United Nations and its specialised agencies, development partners and well meaning Nigerians should come to the aid of Abakaliki and Afikpo prisons, and indeed Nigerian prisons by building a very good structure to accommodate all the inmates in a humanitarian and reformative environment and that would help to improve their welfare. We further recommend as follows.

\subsection{Recommendations}

1. To forestall the problem of overcrowding, as revealed especially in Abakaliki prison where we discovered that we have 914 detainees/convicts in a prison whose capacity is not 387; there is need for urgent expansion of the existing prisons and/or construction of new ones to address congestion and to take account of rising crime rate, which in turn inevitably, leads to an increase in prison population.

2. To minimise the burden of ATM, as evident in both prisons. There is need for urgent proactive action. For example, in Afikpo 138 are ATM, while only 24 are serving their terms after proper court conviction. In Abakaliki prison 848 detainees are awaiting trial, while only 66 are serving their terms after proper court conviction. There is need for the establishment of permanent court houses in the larger prisons, to ease access to justice and liberalisation of bail terms.

3. There is need to ensure that Administration of Justice Committees in the States are established and functional. Regular prison visits by the Chief Judges of the States would help a great deal to speed up trial and reduce congestion. In other words, jail delivery should be conducted on a more regular basis. This will go a long way in decongesting our prisons. This is the view of all the interest groups in the business of justice dispensation. According to Chief Bayo Ojo, former Attorney General of the federation and Minister of Justice, those to benefit from this exercise should be the aged, those with terminal illness, and those whose terms would have expired if they were convicted on time. It was through the Jail Delivery Programme that EBSU Law Clinic secured the release of two prisoners within the period under review (2009). During the jail delivery of the Chief Judge, Hon. Justice A.N. Nwankwo the clinic helped in the release of Ngozi Eden of Igbeagu Izzi and Chukwuma Ereke of Ezza Umuhuali.

4. Establishment of Prison Reforms and Decongestion Commission to coordinate all the necessary reforms and promote synergy in the various sectors of the criminal justice administration. Law clinics should be made part of the synergy in the decongestion reform agenda. EBSU Law Clinic based in this jurisdiction will gladly welcome the synergy and partnership in the area of research, fact finding, paralegal advocacy, interview and counselling, among others.

5. There is need to appoint the Legal Aid Council and National Human Rights Commission as prison inspectors to improve implementation of penal policy. Although these federal government agencies operate minimally at Abakaliki, they have no office at Afikpo. More offices should be sent gto Ebonyi State to cover both prisons. 
6. Provision of an adequate, well trained corps of professional IPOs and Police prosecutors, who should be well distributed within the state. They should not be too frequently transferred.

7. The location of courts should have consideration for proximity to prisons and there should be in place a regular comprehensive evaluation of the prisons to establish their conditions, to determine the kind and extent of intervention needed. This should be on stated intervals.

8. Constitutional amendment that involves the States in the establishment and running of prisons especially as an overwhelming majority of inmates are sent to confinement by State courts for infractions or alleged infractions of State laws. An assumption of responsibility for prisons by the States would make them amenable to accepting reforms especially where such reforms are cost saving.

9. Radically increasing the funding of legal aid, and recognition of University based law clinics as partners in the prison decongestion business.

10. To minimise the problem of lack of access to justice and legal representation by detainees, there should be mandatory provision of legal aid for accused persons in detention.

11. Reform of the legal aid scheme that enables judges to have at all times, a list of lawyers within their jurisdiction in either Abakaliki or Afikpo, who are registered with the legal aid scheme, so that such lawyers can be appointed by the judges as necessary for persons in detention who do not have legal representation.

12. Provision of adequate and functioning transportation for the conveyance of ATMs to court and hospital, where the need arises.

13. Reform of criminal trial system to ensure speed, for instance:

- Imposition of time limits for criminal trials where the accused person is denied or unable to satisfy bail terms.

- Courts within a state, to be given jurisdiction to try detainees regardless of where the offences alleged were committed and, regardless of the detainee's place of detention.

14. Immediate provision of special facilities for the benefit of special categories of prisoners like

- nursing and expectant mothers

- infants

- Prisoners with psychiatric problems

- Prisoners with special medical conditions like HIV/AIDS, TB, and other transmittable diseases.

15. The prisons are old; therefore, there is need for massive renovation of Afikpo prison which was built in 1911 i.e. about a century (100 years) ago by the colonial masters. It comprises of broken-down structures. Cells are constructed from foundation with asbestos and therefore very hot and not fit for habitation. Abakaliki prison built 35 years after Afikpo prison in (1946) also requires extensive renovation to serve the growing capacity of the prison, as part of the structures are almost collapsing.

16. It need not be emphasised that recreation is vital for the physical and mental well-being of the inmates. There is a dearth of recreational facility at Afikpo prison. The ones at Abakaliki are grossly inadequate; hence efforts should be made to provide spaces within the prison yards 
for inmates to have daily exercises Indoor games alone cannot serve as adequate source of recreation for inmates.

17. The vocational facilities aimed at making prisons self sufficient in repairs and minor services should be established. Block moulding industries, electrical and painting workshops should be established. Tailoring workshops should be made more functional to cater for the uniform needs of staff and the inmates at Abakaliki prison. There is near absence of these facilities at Afikpo prison, save tailoring and carpentry. It is recommended that urgent efforts must be made to provide equipment and trainers for shoemaking, barbing, computing, electrical and electronic repairs etc. at Afikpo prison. This will help in eliminating the recidivism in criminal justice system in Nigeria.

18. As is the case with Abakaliki, educational facility should be established in Afikpo prison, as there is none there as at the time of our evaluation. We recommend that, government should establish a standard primary/secondary school and employ qualified teachers to enlighten the inmates. Again, the educational facilities in the prisons should be made functional, as education is a key component of the rehabilitation and reformation process of inmates. There is also need for provision of functional libraries in the prisons. The prisons authority should explore the possibility of liaising with organizations such as Book Aid International (UK), National Commission for Mass Literacy and others, for this purpose, especially Abakaliki prison that already has a school.

19. A functional healthcare facility should be established at Afikpo and resident doctors and nurses deployed. The provision of essential and relevant drugs should be made a priority in the health units of the prisons. In Abakaliki prison, and indeed Afikpo, access to antiretroviral drugs for HIV positive inmates needs to be scaled up. There is also need to provide adequate medical personnel and equipment in all prisons. In addition, special provisions should be made for nursing and/or pregnant mothers taking into consideration their special needs.

20. There is need to provide transport facilities in both prisons to augment the existing one. This is essential, because the absence of transport facilities delay trials and contribute to prison congestion.

21. Water supply is a big challenge to both Abakaliki and Afikpo prisons. Adequate water supply must be provided in all the prisons. The contracting of water supply to water vendors is not reliable. The fetching of water from streams outside the prisons exposes inmates to unsafe water and carries much health and security risks. This must be stopped as soon as practicable. This is because, inadequate water supply means that toilets which are located within the cells give offensive odour thereby making the cells intolerable and increasing the likelihood of the outbreak of epidemics. This should be addressed in line with national and international standards.

22. Similarly, power supply to the prisons must be improved to aid food and drugs storage as well as make prison environment more habitable. It will enhance the welfare and security of inmates and staff. Hence provision of alternative power supply generator that is well maintained and functional is essential.

23. There is urgent need to reduce prison population especially the ATI. Inclusive within this 
broad recommendation is the need to institutionalise prison decongestion schemes and streamline all programmes geared towards decongestion.

24. The environment of Abakaliki prison is a smokescreen from the situation inside. Afikpo prison is deplorable within and outside the cells. It is therefore essential that the conditions of prison cells with particular regard to toilet facilities and ventilation needs immediate improvement for health and security reasons.

25. The increase of the feeding allowance of inmates to N200 per day is a welcome development. This has however not impacted significantly on the quality of food in the prisons. Efforts should be made to ensure efficient application of the improved funding for food in the prisons. In addition, the provision of good food storage facilities in the prisons is recommended as this would improve food handling.

26. Most of the prison staff interviewed, mentioned poor condition of service. The welfare of prison officials needs to be given urgent attention in order to motivate them to provide the services more professionally and appropriately.

27. Similarly, adequate barracks should be built for the officers close to the prisons while the existing barracks which are in a state of disrepair should be renovated. Car loans and housing loans should be organised for prison officials to boost their morale in the job.

28. The prison authority should provide uniforms for the officers at reasonable intervals, considering the need for the officers to be in the uniforms daily and the type of duty some of them are involved in. There is need for them to appear smart at all times so that the inmates can accord them appropriate respect.

29. The prison staff interviewed at both Abakaliki and Afikpo prisons gave inconsistent figures as to the number of inmates in their custody. This is unfortunate. The inability of the prisons to provide accurate necessary data on inmates in their custody should be addressed urgently. Record keeping in prisons should be improved. This should be computerized in line with standards in other establishments and organizations. In this regard, there is need to build the capacity of prison officials in information technology for better record keeping to facilitate study, research and reform efforts in Nigeria prisons.

30. Young and under aged children were sighted in both prisons. There is urgent need to ensure that juveniles are not kept in prisons designated for adults. In this regard, Borstal Institutions should be established in each geo-political zone in the country.

31. To meet international standards, there is urgent need to remove all mentally ill inmates from prisons to psychiatric hospitals or institutions where they can receive appropriate care and treatment for their health conditions. This is particularly vital in Abakaliki prison.

32. The condition of lifers and inmates on death row should be improved. The relevant authorities may commute the sentences appropriately, in view of the unofficial moratorium being enjoyed by such inmates. In this regard, there is need to consider the desirability of abolition of death penalty during the on going constitutional reforms.

33. Stoppage of "holding charge". A situation where people are put in prison custody without charge and pending the completion of investigation makes for over congestion of the prison. This practice would be discouraged in order for the prison to be decongested. According to our findings, most of the inmates are detained on "holding charge". They were remanded 
because the magistrates courts where they were charged under "holding charge" had no jurisdiction. It has been said at the courts and all fora that "holding charge" is not part of Nigerian Law. This should be enforced by a joint effort of the courts, the police and the prison authorities. The policemen always charge respective cases to the appropriate courts. In the same vein, the police should always take or charge the offenders in the court that has the competent jurisdiction to entertain the matter, to avoid declining jurisdiction and dump most innocent people in the prison, in the name of remanding the person.

34. The courts who give remand orders pending advice from the DPP should ensure that return dates are given to ensure expedited compliance, instead of just adjoining the case sine die at the cost of the detained, who may be there sine die!

35. Provision of Prison Alternatives. Penal reform should address the need for the introduction of non custodial measures as an alternative to imprisonment. The absence of prison alternatives like probation or suspended sentence, plea-bargaining, community service, parole, etc. which are absent in Nigeria have gone a long way in compounding prison congestion. These prison alternatives should be provided for non-violent offences like misdemeanour.

36. Compulsory provision of pro-bono services by lawyers and interest groups. Adequate probono services should be provided by lawyers in order to ease-off the over-congestion in Nigerian prison. the resource persons at the Detainees and Indigent Help Centre upheld this point. They maintained that the option of pleading guilty or not guilty does not relieve the prison of heavy traffic since the two still lead suspects to the prison. Therefore, a suspect needs a lawyer to guide and defend him. It noted that the Legal Aid council that would have been doing pro-bono services has not been effective because of poor logistics and inadequate human resources. Therefore, very little help or none at all is coming the way of poor accused persons in Nigeria thereby making them to continue to congest the prisons.

37. Use of prerogative of mercy exercised. The use of prerogative of mercy by the country's president and Governor of a state is one sure way of decongesting the prison. This means the pardoning of a convict on the basis of mercy. This is determined by so many factors among which are: old age, sign of penitence on the part of the convict, long-delay in the dispensation of justice which has led to the accused staying in awaiting trial for a period longer than the time which the accused would have served if convicted on time.

38. Prompt dispensation of justice. There is a saying that justice delayed is justice denied. Quick dispensation of justice is sine-quo-non to good justice. This can be achieved by employing more legal officers, creation of more magisterial districts and judicial divisions. 


\subsection{Conclusion}

The above findings show that prison outreach programmes cannot be timelier than now. It is clear in the two federal prisons studied that most prisons are carrying more than built capacity, due to the problem of "holding charge", lack of legal representation and access to justice, recidivism, slow criminal justice system, and poor judiciary and prison infrastructure, inter alia. This reflects the general prison condition in Nigeria. We in EBSU Law Clinic have decided to use bicycle-type access to justice, leaving Pajero -type justice delivery system to lawyers. Student clinicians are a ready paralegal pool to use to enhance access to justice. Our prison project is poised to change the status quo, and drive towards reform, which the prisons are meant to do. While commending the government on steps taken so far, the government is urged to strengthen efforts to improve the appalling state and living conditions in Nigerian prisons as well as overhaul the criminal justice delivery system. Against the background that prison reforms in isolation of overhauling other arms of justice-delivery would not achieve desired results, we also use this medium to reiterate the need for quick passage of the Prison Act (Amendment Bill) as well as strengthen other measures aimed at reforming the Criminal Justice Administration in Nigeria. If the above findings and recommendations are implemented, the problem of prison congestion will be a thing of the past. 


\section{Appendix A}

\section{Questionnaire}

\section{EBSU LAW CLINIC PRISON DECONGESTION AND FACILITY EVALUATION PROJECT QUESTIONNAIRE (EPDAFEPQ) FOR ABAKALIKI AND AFIKPO FEDERAL PRISONS 2010}

Dear respondent,

This project is aimed at accessing the conditions of the inmates of this prison, with a view to seeing how best the clinic can assist in the decongestion of the prison by providing legal and other services to the inmates. We therefore, beseech you to give us accurate information to the best of your knowledge so that we can assist you optimally. We shall assist you in putting down your answers where necessary.

Thank you.

1 i. Name of inmate:

ii. Nationality:

State of origin

LGA

village

2 i. Age:

ii. Sex:

3. Marital status:

4. Why are you here? (i.e. the offence / accusation what brought you here)

5. For how long?

6. Are you: (a) Awaiting trial / or (b) convicted / or (c) still undergoing trials? (Please underline . the category)

7. If under a or c above, do you have a lawyer representing you? (YES) (NO)

8. If yes, how often do you keep in touch with him/her?

9. Do you think that your prosecution is being delayed? Yes or No (underline)

9. Do you know why your prosecution has been or is being delayed? Yes or No. (circle please ) If yes why

10. Would you like to be freed? 


\section{PRISON FACILITIES ASSESSMENT}

11. What is the state of infrastructural facilities?

Sources of water

i. (Eg. Pipe borne water, bore hole water, well (underline), any other souce

ii. Is the water good Yes No (circle please)

12. Toilet and sanitary facilities:

i. Types of toilet (pit, water closet system, bucket system)

ii. Is the toilet well kept? Yes No (circle please)

iii. Do you have toiletry? Yes No (circle please)

iv. Do you use soap? Yes or No (circle please)

13. Sources of light or power supply

i. $\quad$ PHCN Or Generator Or Lantern Or Candle (Underline)

ii. Is the supply regular? Yes No (circle please)

14 What is the state of the following facilities?

i. Beddings:

(a) Foam, Mat, floor (underline)

(b) Do you share your space with anyone? Yes or No (circle please)

15. Uniforms:

(a) Do the prison authority provide you with uniforms? Yes or No (circle please)

(b) If yes, do you wash it often Yes or No (circle please)

16. What is the state of facilities for worship?

17. What is the state of healthcare facilities and personnel?

i. Healthcare facilities (clinics, Hospital) etc

ii. Healthcare personnel (doctors, nurse etc)

18. Are There Adequate Recreational Facilities? Yes or No (circle please)

If yes name those available

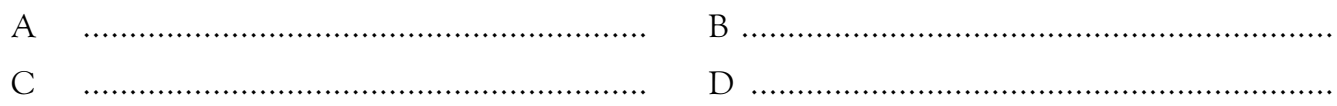

19. Are There Vocational Skill Facilities? Yes Or No (Circle Please)

If Yes name them.

\section{Thank you for your time}

